encouraging experience by comparing routine orthopaedic care, mainly in the acute ward, with geriatrician led care in a small rehabilitation unit with a strong multidisciplinary emphasis. " Some additional costs, not detailed, seem to have been incurred. There were impressive differences in the length of stay, the performance in activities of daily living, and the nature of eventual placement.

The acute orthopaedic ward is a hostile environment for frail elderly patients. In the study by Gilchrist et al transfer to routine or combined care elsewhere took place rather late, around 10 days after admission. ${ }^{10}$ By this time substantial rehabilitation opportunities might have been missed in both groups. In the study by Kennie et al the acute ward served as the control for the duration of the study, probably enhancing the effect of any alternative. Also in this study the inclusion of a scale to measure activities of daily living, a more sensitive outcome measurement than others used, seems to indicate a stronger emphasis on the potential of multidisciplinary rehabilitation. These and other minor differences between the studies might account for their conflicting results.

Geriatric orthopaedic rehabilitation is complex and requires detailed attention to patients' motivation as well as to their clinical and functional problems. And even before patients are considered the problems of logistics, the organisation of staff, and the relation between two very different specialties need to be solved. It follows that evaluating such an endeavour is much less straightforward than evaluating a pill or a procedure.

Others should be encouraged both to take on the task of rehabilitating elderly patients with orthopaedic problems and to measure the impact of their efforts as they do so. Because both orthopaedic and geriatric units vary widely in their resources, working practices, and enthusiasm for the task the nature of cooperation in different centres will vary enormously. But as the demographic imperative is potentially overwhelming and vigorous rehabilitation programmes offer the only hope of substantial reduction of hospital stay all units caring for elderly patients who have been injured now have to try.

Senior Lecturer in Geriatric Medicine,

COLIN T CURRIE

City Hospital, Edinburgh EH10 5SB

\footnotetext{
1 Wallace WA. The increasing incidence of fractures of the proximal femur: an orthopaedic epidemic. Lancet 1983;i:1413-4.

Currie AL, Reid DM, Brown N, Nuki G. An epidemiological study of fracture of the neck of femur. Health Bull (Edinb) 1986;44:143-8.

Lord SR, Sinnett PF. Femoral neck fractures: admissions, bed use, outcome and projections. Med J Aust 1986;145:493-6.

Whitaker JJ, Currie CT. Elderly orthopaedic patients: where they come from and where they go? Health Bull (Edinb) 1988;46:98-104.

Working Party of the Secretary of State for Social Services (Duthie RB, chairman). Report. Orthopaedic services: waiting time for out-patient appointments and inpatient treatment. London Orthopaedic service

6 Boyd RV, Hawthorne J, Wallace WA, Worlock PH, Crompton EH. The Nottingham orthogeriatric unit after 1000 admissions. Injury 1983;15:193-6.

7 Burley LE, Scorgie RE, Currie CT, Smith RG, Williamson J. The joint geriatric orthopaedic service in South Edinburgh. Health Bull (Edinb) 1984;42:133-40.

8 Murphy PJ, Rai GS, Lowy M, Bielswska C. The beneficial effects of joint orthopaedic-geriatric rehabilitation. Age Ageing 1987;16:273-8.

9 Gilchrist WJ, Newman RJ, Hamblen DL, Williams BO. Combined orthopaedic-geriatric care. Lancet $1985 ; \mathrm{i}: 349$.

10 Gilchrist WJ, Newman RJ, Hamblen DL, Williams BO. Prospective randomised study of an orthopaedic geriatric inpatient service. Br Med f 1988;297:1116-8.

11 Kennie DC, Reid J, Richardson IR, Kiamari AA, Kelt C. Effectiveness of geriatric rehabilitative care after fractures of the proximal femur in elderly women: a randomised clinical trial. $\mathrm{Br} \mathrm{Med} \mathcal{f}$ 1988;297:1083-6.
}

\title{
Fibromyalgia syndrome: new research on an old malady
}

\section{A functional syndrome that usually includes pain, fatigue, and disturbance of sleep}

Fibromyalgia is probably as old as mankind. Certainly, musculoskeletal aches and pains in the absence of arthritis, usually called "muscular rheumatism," have been well documented in Europe since the seventeenth century. ${ }^{1}$ In 1904 Sir William Gowers introduced the term fibrositis to describe muscular rheumatism of the back, ${ }^{2}$ and since then nonspecific musculoskeletal pain, usually localised, has been described under names such as fibrositis, myofascial pain, and fibromyositis. ${ }^{13}$ Nevertheless, not until 1968 was the term fibrositis used to describe a well defined syndrome with generalised musculoskeletal aching, stiffness, fatigue, poor sleep, and tenderness at some characteristic sites. ${ }^{45}$

The term fibromyalgia is now preferred to fibrositis, ${ }^{67}$ given that there is no inflammation ${ }^{89}$ and that the term fibrositis had been used previously to describe non-specific aching from heterogeneous causes..$^{1-3}$ Particular attention has recently been paid to the primary fibromyalgia syndrome, defined as non-articular rheumatism with widespread and chronic musculoskeletal aching or stiffness associated with soft tissue tenderness at multiple, characteristic sites in the absence of an underlying cause. ${ }^{+8}$ Surprisingly, in view of the common frequency and symptoms of much pain and dysfunction, ${ }^{1011}$ the first detailed and controlled study of the clinical characteristics of this syndrome was not published until $1981 .{ }^{8}$ Nevertheless, the features are now well recognised, the most important and common being generalised pain, fatigue, and disturbance of sleep. ${ }^{+811-14}$ Commonly associated symptoms include headaches, irritable bowel disturbances, a subjective sense of swelling in articular and periarticular areas, paraesthesiae, and anxiety. Over four fifths of patients are women, usually aged between 20 and 55, though the syndrome is found in children ${ }^{15}$ and the elderly. ${ }^{11}$ The important abnormality on physical examination is the presence of multiple and consistent tender points, and the results of the usual laboratory tests are normal. Positive results on testing for antinuclear antibody in the absence of a known cause have been found in $10-15 \%$ of cases, ${ }^{16}{ }^{17}$ but controlled studies are lacking. The above clinical features have been reported consistently from geographically disparate centres. ${ }^{5812-1418}$

The underlying mechanisms of the primary fibromyalgia syndrome are not well understood. Light and electron microscopic findings in muscle biopsy specimens are normal, ${ }^{9} 19$ although there has been evidence of muscle fibres being connected by a network of reticular fibres, ${ }^{20}$ and of decreased adenosine diphosphate and adenosine triphosphate concentrations, possibly owing to local hypoxia. ${ }^{21}$ Other studies have shown IgG deposition at the dermal-epidermal junction, probably indicating increased vascular permeability, ${ }^{22}$ and increased serotonin receptor binding on platelets. ${ }^{23}$ Serotonin is a modulator of pain and sleep, and its serum concentrations are significantly lower in patients with primary fibromyalgia syndrome than in normal controls ( I J Russell, personal communication).

Hence probably multiple factors, including non-restorative sleep, ${ }^{24}$ physical or mental stress, lack of muscle conditioning, or undefined constitutional factors amplify or contribute to the pain in the fibromyalgia syndrome. ${ }^{2}$ Psychological abnormalities have not been found significantly more commonly in patients seen in a general medicine outpatient 
clinic compared with controls, though they were found in a minority subgroup of patients seen in a referral rheumatology clinic. $^{25}$ The fibromyalgia syndrome shares the features of other well recognised functional disorders, such as the irritable bowel syndrome, tension headache, and primary dysmenorrhoea. All of these syndromes are significantly more common in primary fibromyalgia than in rheumatoid arthritis and normal controls. ${ }^{26}$ Common to fibromyalgia and these other functional syndromes are muscle pain and tenderness, female preponderance or exclusiveness, psychological abnormalities in a minority subgroup of patients, and lack of a specific laboratory test. ${ }^{67}$ The common physiological mechanism in these conditions may well be non-restorative sleep, as has been suggested, ${ }^{27}$ and the important abnormalities are probably neuroendocrine or biochemical rather than anatomical.

The primary fibromyalgia syndrome should be diagnosed on the basis of its own characteristic features and not by exclusion alone. Chronic widespread and diffuse aching at many sites and multiple tender points at characteristic locations in an otherwise healthy patient are important diagnostic considerations. Most patients will have five or more tender points, although as few as two to four among 14 discriminating sites $^{28}$ may be sufficient for the diagnosis if they are very tender. The management includes firm diagnosis and assurance regarding its benign nature, explanation of the probable mechanisms of pain, ${ }^{6}$ gradually increasing physical activity, ${ }^{29}$ use of simple analgesics, prescribing tricyclic agents in small doses, ${ }^{3031}$ and occasional injections of a limited number of tender points with a local anaesthetic and a corticosteroid preparation. ${ }^{6}$ Successful management is facilitated by a caring and understanding doctor who gently but firmly guides the patient to assume responsibility for her own well being. Much can be achieved by doctors who recognise the fibromyalgia syndrome as a characteristic clinical entity and treat their patients with understanding.

Associate Professor of Medicine,

MUHAMMAD B YUNUS

Department of Medicine, Section of Rheumatology,

University of Illinois College of Medicine at Peoria,

Box 1649, Peoria, Illinois 61656

United States
1 Reynolds MD. The development of the concept of fibrositis. $\mathcal{F}$ Hist Med Allied Sci 1983;38:5-35.

2 Gowers WR. Lumbago: its lessons and analogues. Br Med $\mathcal{f}$ 1904;i:117-21.

3 Simons DG. Muscle pain syndromes - part II. Am $\mathcal{Y}$ Phys Med 1976;55:15-42.

4 Traut EF. Fibrositis. $\mathcal{f}$ Am Geriatr Soc 1968;16:531-8.

5 Smythe HA. Non-articular rheumatism and the fibrositis syndrome. In: Hollander JL, McCarty DJ Jr, eds. Arthritis and allied conditions, 8th ed. Philadelphia: Lea and Febiger, 1972:874-84.

6 Yunus MB. Diagnosis, etiology and management of fibromyalgia syndrome: an update. Compr Ther 1988;14:8-20.

7 Yunus MB. Fibromyalgia syndrome: a need for uniform classification. $f$ Rheumatol 1983;10:8414.

8 Yunus MB, Masi AT, Calabro JJ, et al. Primary fibromyalgia (fibrositis): clinical study of 50 patients with matched normal controls. Semin Arthritis Rheum 1981;11:151-71.

9 Kalyan-Raman UP, Kalyan-Raman K, Yunus MB, Masi AT. Muscle pathology in primary fibromyalgia syndrome: a light microscopic, histochemical and ultrastructural study. I Rheumatol 1984;11:808-13.

10 Cathey MA, Wolfe F, Kleinheksel SM. Functional ability and work status in patients with fibromyalgia. Arthritis Care and Research 1988;1:85-8.

11 Yunus MB, Holt GS, Masi AT, Aldag JC. Fibromyalgia syndrome among the elderly: comparison with younger patients. I Am Geriatr Soc 1988;36:987-95.

12 Campbell SM, Clark S, Tindall EA, et al. Clinical characteristics of fibrositis: I. A "blinded," controlled study of symptoms and tender points. Arthritis Rheum 1983;26:817-24.

3 Wolfe F, Hawley DJ, Cathey MA, et al. Fibrositis: symptom frequency and criteria for diagnosis. $\mathcal{J}$ Rheumatol 1985;12:1150-63.

14 Goldenberg DL. Fibromyalgia syndrome: an emerging but controversial condition. JAMA 1987;25:2782-7.

15 Yunus MB, Masi AT. Juvenile primary fibromyalgia syndrome: a clinical study of 33 patients and matched normal controls. Arthritis Rheum 1985;28:138-45.

16 Yunus MB, Masi AT. Prevalence of antinuclear antibodies and connective tissue disease symptoms in primary fibromyalgia syndrome. Clin Res 1985;33:924A.

17 Dinerman H, Goldenberg DL, Felson DT. A prospective evaluation of 118 patients with the fibromyalgia syndrome. I Rheumatol 1986;13:368-73.

18 Bengtsson A, Henriksson K-G, Jorfeldt L, et al. Primary fibromyalgia: a clinical and laboratory study of 55 patients. Scand 7 Rheumatol 1986;15:340-7.

19 Yunus MB, Kalyan-Raman UP, Masi AT, Aldag JC. Electron microscopic studies of muscle biopsy in primary fibromyalgia syndrome: a controlled and blinded study. $\mathcal{F}$ Rheumatol (in press).

20 Bartels EM, Danneskiold-Samsøe B. Histological abnormalities in muscle from patients with certain types of fibrositis. Lancet 1986; i:755-7.

21 Bengtsson A, Henriksson KG, Larsson J. Reduced high-energy phosphate levels in the painful muscles of patients with primary fibromyalgia. Arthritis Rheum 1986;29:817-21.

22 Caro XJ, Wolfe F, Johnston WH, Smith AL. A controlled and blinded study of immunoreactant deposition at the dermal-epidermal junction of patients with primary fibrositis syndrome. f R heumatol 1986;13:1086-92.

23 Russell IJ, Bowden CL, Michalek J, et al. Imipramine receptor density on platelets of patients with fibrositis syndrome; correlation with disease severity and response to therapy. Arthritis Rheum 1987;30:S63.

24 Moldofsky H, Scarisbrick P, England R, Smythe H. Musculoskeletal symptoms and non-REM sleep disturbance in patients with fibrositis syndrome and healthy subjects. Psychosom Med 1975;37:341-51.

25 Goldenberg DL. Psychologic studies in fibrositis. Am $\mathcal{F}$ Med 1986:81:67-70.

26 Yunus MB, Masi AT, Aldag JC. A controlled study of primary fibromyalgia syndrome: clinical features and association with other functional syndromes. $\mathcal{F}$ R heumatol (in press).

27 Bennett RM. Fibrositis: evolution of an enigma. $\mathcal{F}$ Rheumatol 1986;13:676-8.

28 Yunus MB, Masi AT, Aldag JC. Preliminary criteria for primary fibromyalgia syndrome (PFS): multivariate analysis of a consecutive series of PFS, other pain patients and normal subjects. Clin Exp Rheumatol (in press).

29 McCain GA, Bell DA, Mai FM, Holliday PD. A controlled study of the effects of a supervised cardiovascular fitness training program on the manifestations of primary fibromyalgia. Arthritis Cardiovascular fitness trainin

30 Goldenberg DL, Felson DT, Kinerman H. A randomized controlled trial of amitriptyline and naproxen in the treatment of patients with primary fibromyalgia. Arthritis Rheum 1986;29: $1371-7$

31 Carette S, McCain GA, Bell DA, Fam AG. Evaluation of amitriptyline in primary fibrositis: a double-blind, placebo-controlled study. Arthritis Rheum 1986;29:655-9.

\section{Gonadotrophin releasing hormone analogues for gynaecological disorders and infertility}

\section{A real advance}

Repeated administration of gonadotrophin releasing hormone agonists initially stimulate but then desensitise the pituitary cells responsible for producing the gonadotrophins. This specific deprivation of gonadotrophin support to the gonads has been used for treating disorders dependent on the sex hormones and, paradoxically, also infertility. Pilot studies for the treatment of endometriosis, uterine fibroids, menorrhagia, the premenstrual syndrome, the polycystic ovary syndrome, and timed induction of ovulation have proved promising. We now have the results of large scale clinical trials and have begun to evaluate the consequences of long term suppression of oestrogen concentrations so that the place of these agents in clinical practice can be objectively assessed.

In the two largest multicentre randomised studies of these agonists in treating endometriosis 213 women were treated for six months with either danazol or the agonist nafarelin' ${ }^{1}$ and 172 women with danazol or buserelin. ${ }^{2}$ Both treatments were equally effective in reducing American Fertility Society scores and symptoms and over four fifths of patients benefited from treatment. The patients found the side effects of danazol less acceptable, however, than those of the agonists, though danazol may have advantages over agonists because of its immunosuppressive effects - which may be important if autoimmunity has a role in the disease, as has recently been postulated. ${ }^{3}$ Many patients with endometriosis present with infertility. Conception rates are $30-50 \%$ during the six mon ; after treatment with either gonadotrophin releasing hormo. : agonist or danazol, but we need large scale double blind controlled trials before we know whether there is any real advantage of treatment with either of these drugs over 